\title{
Development of Intergeneric Canine Embryo Using Bovine and Porcine Oocyte as Cytoplasm Recipient
}

\author{
Yuda Heru Fibrianto \\ Department of Physiology, Faculty of Veterinary Medicine, Gadjah Mada University
}

\begin{abstract}
This study was conducted to increase the efficiency of canine embryo production by intergeneric somatic cell nuclear transfer (SCNT) technology. The effect of oocyte recipient for development of intergeneric canine somatic cell cloning embryos were examined. Bovine and porcine cumulus oocyte complexes (COCs) were collected from slaughterhouse ovaries and matured in TCM-199 medium depend on species. Adult dog fibroblasts collected from 3.5 years old Afghanhound dog, and cell between passage 1 and passage 10 used for intergeneric somatic cell cloning using bovine and porcine oocytes as oocyte cytoplasm donor. The result showed that oocytes from bovine and porcine can de-differentiated canine nucleus and no different between bovine and porcine oocyte in fusion and embryo development in vitro. Canine intergeneric cloned embryos developed to morula stages in vitro.
\end{abstract}

Keyword: canine, intergeneric cloning, SCNT, mSOF

\section{Introduction}

Interspecies somatic cell nuclear transfer method was firstly applied for conservation of endangered animals. The highly publicized that an adult sheep had been cloned from the nucleus of a frozen somatic cell (Wilmut et al., 1997) speculated that cloning technologies might be applied to increase population sizes of endangered species, or even restore them following extinction (Cohen, 1997; Wen et al., 2005). Interspecies nuclear transfer also provides a possible approach to clone animal species whose oocytes were difficult to obtain (Jumnian et al., 2002; Wen et al., 2003).

Several studies have shown that oocyte cytoplasm from bovine, rabbits and sheep can support early development of embryos produced by nuclear transfer of somatic cells nuclei from various mammalian species (Dominko et al., 1999; White et al., 1999;

Corresponding author: Yuda Heru Fibrianto, Department of Physiology, Faculty of Veterinary Medicine, Gadjah Mada University, Jl. Olah Raga Karangmalang, Yogyakarta 55281, Indonesia. Tel: 62-274-649-62415; Email: yudaf@ugm.ac.id
Cohen et al., 1997; Lanza et al., 1999; Chen et al., 2002; Wen et al., 2003). Recently, the successes of cloning gaur (Lanza et al., 2000) and mouflon (Loi et al., 2001) have demonstrated that the technique of interspecies cloning can be practically applied to save highly endangered species, such as the giant panda, Ovis orientalis musimon, buffalo, Bos gaurus (White et al., 1999; Lanza et al., 2000; Vogel et al., 2001; Chen et al., 2002; Jumnian et al., 2002; Sansisena et al., 2005).

The oocyte used for interspecies nuclear transfer should be easy to obtain, able to dedifferentiate other species nuclei and support development the hybrid embryos (Wen et al., $2003 ; 2005)$. There are basically two approaches to the success of the application of nuclear transfer (NT) technology in any given species: 1) to adjust the multiple parameters that affect the overall efficiency of the NT procedure and 2) to explore the use of a more readily available, universal recipient ooplasm for NT in species were the availability of oocytes is restricted. 
The bovine ooplasm has been shown to be able to reprogram somatic cell nuclei from other species. After transfer into enucleated, metaphase II (MII) bovine oocytes, nuclei from sheep, pig, monkey and rat skin cells underwent swelling. It was reported that cell division and formation of an embryonic blastocoele cavity occurred at the time characteristic of embryos from the species of the donor nuclei (Dominko et al., 1999).

The first experiments of intergeneric NT in mammals, in which he transferred the rat spindle into nucleated MII mouse oocytes, but the rat-mouse hybrid embryos could not develop beyond the eigh-cell stage. Successful interspecies and intergeneric NT, either giving birth to live offspring or producing nearly termed fetuses, has been achieved by several groups concerned with the preservation of endangered species. When dermal fibroblast of andangered bovid, the gaur (Bos gaurus) (Lanza et al., 2000), granulose cells from an endangered sheep, the mouflon (Ovis orientalis musimon) (Loi et al., 2001), fetal fibroblasts from water buffalo (Bubalus bubalis) (Lu et al., 2005) and ear fibroblast of takin (Budorcas taxicolor) were introduced into enucleated oocyte of cow, sheep and cow, $12 \%, 30 \%, 33 \%, 13 \%$ and $5 \%$ of the reconstructed embryos developed to the blastocyst stage, respectively. Another experiment reported by Wen et al. (2005) used rabbit ooplast as recipient for panda and cat somatic nuclei and found $8 \%, 7 \%$ of the reconstructed embryos developed to the blastocyst stage, respectively.

The first interspecies NT offspring was reported for the gaur by Lanza et al. (2000) but unfortunately died within the first 48 hours. Using domestic sheep (Ovis aries) as recipient cytoplasts two pregnancies were established after interspecies NT using an exotic argali (Ovis ammon) for donor karyoplasts, however both of these pregnancies were reported to have been lost by 59 days of gestation (White et al., 1999). More recently, domestic sheep (Ovis aries) enucleated oocytes used as cytoplasts for adult mouflon cells (Ovis orientalis musimon) resulted on one live offspring (Loi et al., 2001).

Interspecies NT studies using the bovine cytoplasts as a universal recipient included the injection of somatic cells from pigs (Lee., 2003), saolas (Bui et al., 2002), elands (Damiani et al., 2003), horses (Sansisena et al., 2002) and humans (Cibelli et al., 1998), and also Wen et al. (2005) using rabbit MII oocyte for panda or cat somatic nuclei, however no confirmed pregnancies have been reported. In addition, equine enucleated oocytes have been used as recipients for somatic cells from a mule fetus producing pregnancies (Woods et al., 2003).

The use of alternative NT techniques, such as interspecies NT, is an exciting possibility for species with limited availability of oocytes and recipients as well as for endangered or exotic species. Although some studies have shown promising results initially, the mechanisms of nuclear reprogramming by the oocyte are still unknown and the extent of the universality of the bovine cytoplast remains under investigation

The aim of these studies was to know the oocyte recipient to the best support for canine nuclei in nuclear transfer.

\section{Materials and Methods}

Collection of oocytes and in vitro maturation (IVM) of bovine oocyte

Bovine ovaries from Holstein cows were collected from a local slaughterhouse and transported to the laboratory within $2 \mathrm{~h}$ in $0.9 \%(\mathrm{w} / \mathrm{v}) \mathrm{NaCl}$ solution at $35^{\circ} \mathrm{C}$. Cumulusoocyte complexes (COCs) were retrieved from antral follicles 2-8 $\mathrm{mm}$ in diameter by aspiration with an 18-gauge hypodermic needle attached to a $10 \mathrm{ml}$ disposable syringe. The COCs with evenly granulated 
cytoplasm and enclosed by more than three layers of compact cumulus cells were selected, washed three times in HEPESbuffered tissue culture medium (TCM)-199 (Life Technologies, Rockville, MD) supplemented with $0.5 \%(\mathrm{w} / \mathrm{v})$ BSA (fatty acid free, fraction V, Sigma-Aldrich Corp., St. Louis, MO), $2 \mathrm{mM}$ sodium bicarbonate and $10 \mathrm{mM}$ HEPES (Sigma-Aldrich) and 1\% $(\mathrm{v} / \mathrm{v})$ solution of penicillin and streptomycin (Sigma-Aldrich) (Tabel 1). For maturation, COCs were cultured in four-well dishes (3040 COCs per well, Nunclon, Roskilde, The Netherlands) for $20-22 \mathrm{~h}$ in $500 \mu \mathrm{l}$ bicarbonate-buffered

TCM-199 supplemented with $10 \%(\mathrm{v} / \mathrm{v})$ fetal bovine serum (FBS) (Life Technologies), $0.005 \mathrm{U} / \mathrm{ml}$ bovine FSH (Antrin $^{\circledR}$, Denka Kanagawa, Japan) and $1 \mu \mathrm{g} / \mathrm{ml}$ estradiol (SigmaAldrich) at $39^{\circ} \mathrm{C}$ in a humidified atmosphere of $5 \% \mathrm{CO}_{2}$ in air.

\section{Preparation of recipient oocytes for somatic} cell nuclear transfer (SCNT)

At 20-22 h of maturation culture, expanded cumulus cells of COCs were removed by repeated pipetting in $0.1 \%$ hyaluronidase in hCR2aa (HEPES-Charles Rosenkrans 2 aminoacid) (Table 2), and oocytes with first polar bodies were selected. Oocytes were then enucleated in hCR2aa supplemented with $10 \%$ FBS and $7 \mu \mathrm{g} / \mathrm{ml}$ cytochalasin B (Sigma-Aldrich) under an inverted microscope equipped with a micromanipulation system (Narishige, Tokyo, Japan). Each oocyte was held with a holding micropipette $(110 \mu \mathrm{m}$ outer diameter and $24 \mu \mathrm{m}$ inner diameter) and the zona pellucida was partially dissected with a fine glass needle to create a slit near the first polar body. The first polar body and adjacent cytoplasm presumably containing the MII chromosomes were extruded by squeezing with the needle. Oocytes were then stained with $5 \mu \mathrm{g} / \mathrm{ml}$ bisbenzimide (Hoechst 33342, Sigma-Aldrich) for $15 \mathrm{~min}$ and observed under an inverted microscope equipped with epifluorescence at 200X magnification. Oocytes still containing DNA material were excluded. The enucleated oocytes were placed in TCM-199 supplemented with 10\% FBS and used for SCNT.

Table 1. Composition of tissue culture medium 199 (TCM199) medium for IVM

\begin{tabular}{|c|c|c|c|}
\hline \multirow[t]{2}{*}{ Substrates } & \multirow{2}{*}{$\begin{array}{r}\text { Bovine } \\
\text { Washing }\end{array}$} & \multicolumn{2}{|c|}{ Porcine } \\
\hline & & Culture & Culture \\
\hline & Gibco & & \\
\hline Tissue & 31100 027 & & \\
\hline culture & (in 1 liter & Gibco & Gibco \\
\hline medium & $\begin{array}{l}\text { distilled } \\
\text { water) }\end{array}$ & $11150 \sim 059$ & $11150 \sim 059$ \\
\hline HEPES 1 & $10 \mathrm{mM}$ & $\sim$ & \\
\hline Na pyruvate & $\sim$ & $1 \mathrm{mM}$ & $0.91 \mathrm{mM}$ \\
\hline Glucose & $\sim$ & $\sim$ & $3.05 \mathrm{mM}$ \\
\hline $\mathrm{NaHCO}_{3}$ & $2 \mathrm{mM}$ & $26.2 \mathrm{mM}$ & $26.2 \mathrm{mM}$ \\
\hline L-cysteine & $\sim$ & $\sim$ & $0.57 \mathrm{mM}$ \\
\hline $\begin{array}{l}\text { Calsium } \\
\text { (lactate) }\end{array}$ & & & $2.92 \mathrm{mM}$ \\
\hline PFF & $\sim$ & $\sim$ & $10 \%(\mathrm{v} / \mathrm{v})$ \\
\hline $\begin{array}{l}\text { Fetal Bovine } \\
\text { Serum }\end{array}$ & $\sim$ & $10 \%(\mathrm{v} / \mathrm{v})$ & $\sim$ \\
\hline $\begin{array}{c}\text { Bovine Serum } \\
\text { Albumin }\end{array}$ & $0.5 \%(\mathrm{w} / \mathrm{v})$ & $\sim$ & $\sim$ \\
\hline Pen-strept & $1 \%(\mathrm{v} / \mathrm{v})$ & $1 \%(\mathrm{v} / \mathrm{v})$ & $1 \%(\mathrm{~V} / \mathrm{V})$ \\
\hline
\end{tabular}

\section{Injection, fusion and activation oocytes}

Trypsinized, a single cells with a smooth surface were selected under an inverted microscope equipped with a fluorescent isothiocyanate (FITC) filter (wavelength: excitation $489 \mathrm{~nm}$ and emission $508 \mathrm{~nm}$ ) and were transferred into the perivitelline space of enucleated oocytes through the same slit that was made during enucleation. The couplets were subsequently placed in a fusion medium comprising $0.26 \mathrm{M}$ mannitol, $0.1 \mathrm{mM} \mathrm{MgSO}_{4}, 0.5 \mathrm{mM}$ HEPES and $0.05 \%$ $(\mathrm{w} / \mathrm{v}) \mathrm{BSA}$, and transferred into a cell fusion chamber with a stainless steel electrode (3.2 mm gap; BTX Inc., San Diego, CA) after equilibration for $3 \mathrm{~min}$. Fusion was induced 
by two DC pulses of $1.75 \mathrm{kV} / \mathrm{cm}$ for $15 \mu \mathrm{s}$ using an Electro-cell Manipulator 2001 (BTX Inc). The fusion of the donor cell and the ooplast was determined $1 \mathrm{~h}$ after electric stimulation under a stereomicroscope (Nikon Corp., Tokyo, Japan). Only fused embryos were selected and subjected to chemical activation. For transgenic embryos, fusion was confirmed by observing GFP expression in recipient cytoplasm under DIC microscopy equipped with FITC filter (Nikon Corp.). Chemical activation was induced by incubating embryos in HEPESbuffered TCM-199 (hTCM) containing $5 \mu \mathrm{M}$ ionomycin (Sigma-Aldrich) for $4 \mathrm{~min}$ at $39^{\circ} \mathrm{C}$. Reconstructed embryos were then washed thoroughly in ionomycin-free hTCM and further incubated for $4 \mathrm{~h}$ in modified

Table 2. Composition of Hepes-buffered Charles Rosenkrans 2 with amino acids medium for embryo handling

\begin{tabular}{lc}
\hline Substrate & Concentrations \\
\hline $\mathrm{NaCl}$ & $114 \mathrm{mM}$ \\
\hline $\mathrm{KCl}$ & $3.1 \mathrm{mM}$ \\
\hline $\mathrm{NaHCO} 3$ & $2 \mathrm{mM}$ \\
\hline $\mathrm{NaH} 2 \mathrm{PO} 4$ & $0.35 \mathrm{mM}$ \\
\hline Sod. Lactate & $15 \mathrm{mM}$ \\
\hline CaCl2.2H2O & $2 \mathrm{mM}$ \\
\hline $\mathrm{MgCl} 2.6 \mathrm{H} 2 \mathrm{O}$ & $0.5 \mathrm{mM}$ \\
\hline $\mathrm{NEAA} 1$ & $1 \%(\mathrm{v} / \mathrm{v})$ \\
\hline ITS2 & $1 \%(\mathrm{v} / \mathrm{v})$ \\
\hline Glycine & $0.37 \mathrm{mM}$ \\
\hline Citrate & $0.33 \mathrm{mM}$ \\
\hline HEPES3 & $10.5 \mathrm{mM}$ \\
\hline Phenol red & $10 \mu \mathrm{g} / \mathrm{L}$ \\
\hline FBS4 & $10 \%(\mathrm{v} / \mathrm{v})$ \\
\hline P/S5 & $1 \%(\mathrm{v} / \mathrm{v})$ \\
\hline
\end{tabular}

${ }^{1}$ Non essential amino acids.

${ }^{2}$ Insulin $(10 \mu \mathrm{g} / \mathrm{ml})$, transferrin $(5.5 \mu \mathrm{g} / \mathrm{ml})$, selenium (5 $\mathrm{ng} / \mathrm{ml})$.

${ }^{3} \mathrm{~N} \sim[2 \sim$ Hydroxyethyl]piperazine $\sim \mathrm{N} \sim$

[2 ethanesulfonic acid],

${ }^{4}$ Fetal bovine serum,

${ }^{5}$ Penicillin 10,000IU, Streptomycine $10 \mathrm{mg} / \mathrm{L}$. synthetic oviduct fluid (mSOF) (Table 3) medium supplemented with $1.9 \mathrm{mM}$ 6dimethylaminopurine (Sigma-Aldrich).

\section{In vitro culture (IVC)}

A group of 5-7 reconstructed embryos were cultured in a $25 \mu \mathrm{l}$ microdrops of SOF media supplemented with $0.8 \%$ BSA (Choi et al., 2002) under embryo-tested mineral oil at $39^{\circ} \mathrm{C}$ with $5 \% \mathrm{CO}_{2}, 5 \% \mathrm{O}_{2}$ and $90 \% \mathrm{~N}_{2}$ in a humidified atmosphere. The embryos were evaluated at 48 and $192 \mathrm{~h}$ after activation for embryo development. The GFP expression in embryo was determined under a FITC filter.

Collection of oocytes and in vitro maturation (IVM) of porcine oocyte

Ovaries were obtained from a local abattoir and transported to the laboratory in physiological saline at 30 to $35^{\circ} \mathrm{C}$. Antral follicles 3 to $6 \mathrm{~mm}$ in diameter were aspirated using an 18-gauge needle attached to a 5-ml disposable syringe. COCs with compact cumulus cells were collected from the aspirate and washed several times in TCM199. The COCs were then placed in IVM medium (Earle's salts- and L-glutaminecontaining TCM-199 supplemented with 26.2 $\mathrm{mM} \mathrm{NaHCO}, 3.05 \mathrm{mM}$ glucose, $0.91 \mathrm{mM}$ sodium pyruvate, $0.57 \mathrm{mM}$ L-cysteine, 75 $\mathrm{mg} / \mathrm{l}$ kanamycin, $10 \mathrm{ng} / \mathrm{ml}$ epidermal growth factor (Sigma-Aldrich), equine chorionic gonadotropin (eCG, Intervet, Boxmeer, Netherland), $10 \mathrm{IU} / \mathrm{ml}$ human chorionic gonadotropin (hCG, Intervet Boxmeer Netherland), and $10 \%(\mathrm{v} / \mathrm{v})$ porcine follicular fluid (pFF) (Table 1). The pFF was aspirated from superficial antral follicles 8 to $10 \mathrm{~mm}$ in diameter from prepubertal gilts. After centrifugation at $1,600 \times \mathrm{g}$ for $30 \mathrm{~min}$, supernatant was collected and filtered sequentially through $1.2 \mu \mathrm{m}$ and $0.45 \mu \mathrm{m}$ syringe filters (Gelman 
Sciences, Ann Arbor, MI, USA). Prepared pFF was then stored at $-20^{\circ} \mathrm{C}$ until use.

A group of 50 COCs was cultured in 500 $\mu \mathrm{IVM}$ medium at $39^{\circ} \mathrm{C}$ in a humidified atmosphere of $5 \% \mathrm{CO}_{2}$ and $95 \%$ air. After culturing for $22 \mathrm{~h}$, COCs were transferred to eCG- and hCG-free IVM medium and cultured further for 20-22 h. At the end of the culture, oocytes were freed from cumulus cells by repeated pipetting in IVM medium containing $0.1 \%$ hyaluronidase. Oocytes with a first polar body, intact zona pellucida, evenly granulated cytoplasm, expanded cumulus cells and distinct ooplasmic membrane were provided for SCNT of this study.

\section{Preparation of recipient oocytes for somatic cell nuclear transfer}

After 42-44 h of maturation, the oocytes were freed from cumulus cell by pipetting in HEPES-buffered NCSU-23 medium supplemented with $0.1 \%$ hyaluronidase. Oocytes were cultured in NCSU-23 containing $5 \mu \mathrm{g} / \mathrm{ml}$ bisbenzimide (Hoechst 33342; Sigma-aldrich Co.) and $7.5 \mu \mathrm{g} / \mathrm{ml}$ cytochalasin B for $30 \mathrm{~min}$. Oocytes were placed in a $4 \mu \mathrm{l}$ drop of HEPES-buffered NCSU-23 medium on working dishes. Each recipient oocyte was held with a holding micropipette $(110 \mu \mathrm{m}$ in outer and $24 \mu \mathrm{m}$ in inner diameter) and zona pellucida was partially dissected with a fine glass needle to create a slit near the polar body. Then, the first polar body and adjacent cytoplasm containing metaphase plate were removed by squeezing. Enucleated oocyte were visually verified by ultraviolet fluorescence, keeping exposure to a minimum. The enucleated oocytes were then placed in NCSU23-D and used for SCNT.

\section{Injection, electrofusion and activation}

Injection was performed in $4 \mu \mathrm{l}$ drop of HEPES-buffered NCSU23-W medium and covered with light mineral oil. A single cell with smooth membrane was transferred into the perivitelline space of an enucleated oocyte. Before nuclear transfer, transfected donor cell were identified emission of green fluorescence under an epifluorescent microscope using a standard FITC filter set. Round-shaped and green-colored small cell were individually injected into perivitelline space of enucleated oocytes.

Reconstructed oocytes were fused and activated simultaneously. The reconstructed oocytes were equilibrated for $10 \mathrm{sec}$ in fusion medium (0.26 M mannitol, $0.1 \mathrm{mM} \mathrm{MgCl}_{2}$, $0.1 \mathrm{mM} \mathrm{CaCl}, 0.5 \mathrm{mM}$ HEPES and $0.05 \%$ BSA) and transfer to a fusion chamber with two electrodes ( $3.2 \mathrm{~mm}$ gap) overlaid with the mannitol medium. Reconstructed oocytes (5-7 oocytes) were aligned with a fine mouth-controlled Pasteur pipette in parallel with a fusion chamber.

Table 3. Composition of modified synthetic oviduct fluid (mSOF)

\begin{tabular}{lc}
\hline Ingredient & Concentrations \\
\hline $\mathrm{NaCl}$ & $100 \mathrm{mM}$ \\
$\mathrm{KCl}$ & $7.2 \mathrm{mM}$ \\
\hline $\mathrm{NaHCO} 3$ & $25.1 \mathrm{mM}$ \\
\hline $\mathrm{KH} 2 \mathrm{PO} 4$ & $1.2 \mathrm{mM}$ \\
\hline Sod. Lactate & $3.3 \mathrm{mM}$ \\
\hline $\mathrm{CaCl} 2.12 \mathrm{H} 2 \mathrm{O}$ & $2 \mathrm{mM}$ \\
\hline $\mathrm{MgCl} 2.16 \mathrm{H} 2 \mathrm{O}$ & $0.5 \mathrm{mM}$ \\
\hline EAA1 & $2 \%(\mathrm{v} / \mathrm{v})$ \\
\hline $\mathrm{NEAA} 2$ & $1 \%(\mathrm{v} / \mathrm{v})$ \\
\hline Sod. Pyruvate & $0.3 \mathrm{mM}$ \\
\hline Glucose & $1.5 \mathrm{mM}$ \\
\hline BSA3 & $8 \mathrm{mg} / \mathrm{ml}$ \\
\hline L-Glutamine & $1 \mathrm{mM}$ \\
\hline ITS4 & $0.5 \%(\mathrm{v} / \mathrm{v})$ \\
\hline P/S5 & $1 \%(\mathrm{v} / \mathrm{v})$ \\
\hline
\end{tabular}

${ }^{1}$ Essential amino acids

2 Non-essential amino acid

${ }^{3}$ Bovine serum albumin (fatty acid free, fraction $\mathrm{V}$ ) ${ }_{4}^{4}$ Insulin $(10 \mu \mathrm{g} / \mathrm{ml})$, transferrin $(5.5 \mu \mathrm{g} / \mathrm{ml})$ and selenium $(5 \mathrm{ng} / \mathrm{ml})$

${ }_{5}^{5}$ Penicillin 10,000 IU, Streptomycin $10 \mathrm{mg} / \mathrm{L}$ 
Fusion was induced with a single DC pulse of $1.86 \mathrm{kV} / \mathrm{cm}$ for $30 \mu \mathrm{s}$, by on a Electrocell Manipulator 2001. All treated oocytes were washed three times with NCSU23-W supplemented with $4 \mathrm{mg} / \mathrm{ml}$ BSA, placed in $25 \mu 1$ microdrops (10-15 oocytes per drop) of NCSU23-D under mineral oil and cultured at $39^{\circ} \mathrm{C}, 5 \% \mathrm{CO}_{2}, 5 \% \mathrm{O}_{2}$ and $90 \% \mathrm{~N}_{2}$. Fused oocytes were determined one hour after the electrical pulse under microscope.

\section{Statistical analysis}

Data from all experiments were analyzed using the statistical Analysis System (SAS) program. Data were subjected to analysis of variance (ANOVA) and protected least significant different (LSD) test to determine differences among experimental groups. When a significant model effect was found in each experimental parameter, data were compared by the least squares method. Statistical significance was determined where P value was less than 0.05 .

\section{Subsequent culture}

The reconstructed embryos were cultured in $25 \mu \mathrm{l}$ drops of NCSU23-D overlaid with mineral oil at $39^{\circ} \mathrm{C}$ in humidified $5 \% \mathrm{CO}_{2}, 5 \% \mathrm{O}_{2}$ and $90 \% \mathrm{~N}_{2}$ atmosphere. Ten to fifteen embryos were cultured together. Cleavage rate was recorded after $48 \mathrm{~h}$ post fusion. On 7 days post fusion, the development of reconstructed embryos was recorded, and GFP expression rate in embryo was examined under FITC filter.

\section{Preparation of donor canine cells}

Canine fibroblast cells were isolated from ear skin. The external surface of canine ear skin was shaved and cleaned aseptically. A piece of ear skin tissue about $100 \mathrm{~mm}^{3}$ wide and $2 \mathrm{~mm}$ thick was biobsied and immediately immersed in D-PBS (Life technologies). After washing, the tissues were minced by a surgical blade on a $100 \mathrm{~mm}$ culture dish, followed by dissociation by $0.25 \%(\mathrm{w} / \mathrm{v})$ trypsin containing $1 \mathrm{mM}$ EDTA for 1 to $2 \mathrm{~h}$ at $38^{\circ} \mathrm{C}$. Trypsinized cells were washed once by centrifugation $(300 \mathrm{Xg}, 2$ $\mathrm{min}$ ) and subsequently seeded into $100 \mathrm{~mm}$ culture dishes and cultured for 6-8 day in Dulbecco's modified Eagle medium (DMEM) supplemented with 10\% (v/v) FBS, $1 \mathrm{mM}$ sodium pyruvate, $1 \%$ (v/v) nonessential amino acid and $10 \mu \mathrm{l} / \mathrm{ml}$ penicillin/ streptomycin solution in a humidified atmosphere of $95 \%$ air, $5 \% \mathrm{CO}_{2}$ at $38^{\circ} \mathrm{C}$ before removal of unattached clumps of cells or explants. The attached cells were passage by trypsinization when confluent.

\section{Experimental studies}

Effect of oocyte recipient on development rate of intergeneric canine embryo

In vitro developmental rates of NT embryos produced by transferring canine cell into enucleated MII bovine and porcine oocytes was examined. Forty eight $h$ after cultured, embryos were examined for cleavage rate and $172 \mathrm{~h}$ for final development. Embryos derived from nuclear transfer of canine donor cells to bovine or porcine oocyte were randomly distributed and cultured for $192 \mathrm{~h}$ in $\mathrm{mSOF}$ for bovine and $144 \mathrm{~h}$ in NCSU23-D for porcine, development of embryo control by the $48 \mathrm{~h}$ after cultured in media.

\section{Results}

Effect of cytoplasmic recipient on development of canine interspecies embryo

A total 274 bovine oocyte and 303 porcine oocyte are used in this experiment. The fusion rate of reconstructed almost similar between couplets canine cell and bovine or porcine oocyte and have no statistically different between them. Porcine oocyte have $68 \%$ fusion rate and bovine give $66 \%$ fusion with canine cell. The cleaved rate from bovine oocyte have $58 \%$ and from porcine oocyte $72 \%$ and embryo 


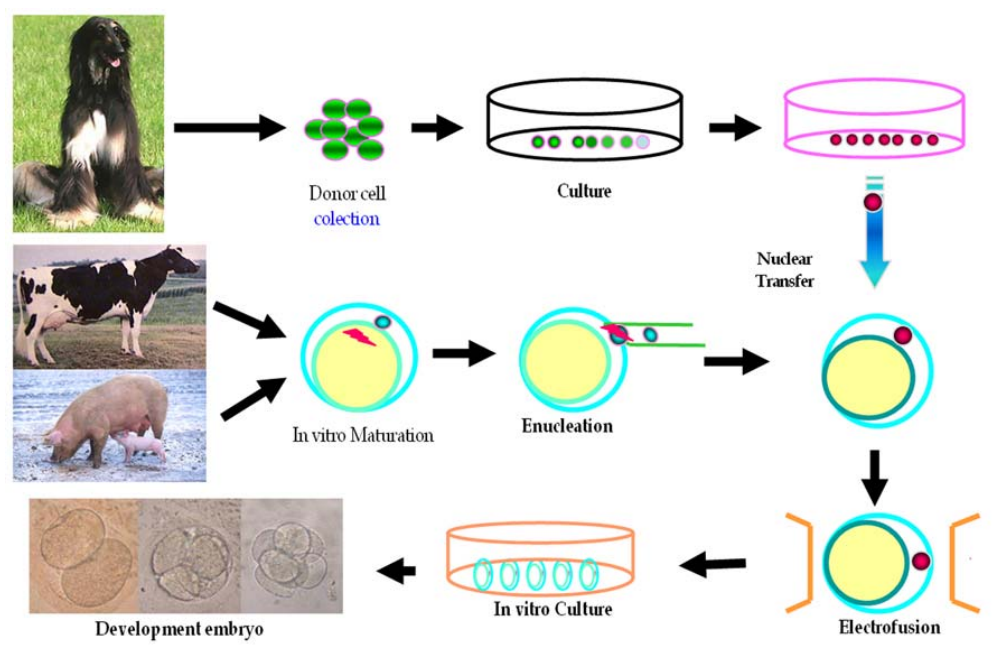

Figure 1. Scheme of somatic nuclear transfer technology

development between both of oocyte recipient almost same at $8-16$ cell stage $54 \%$ for porcine and $51 \%$ for bovine and the same morula stage rate within porcine and bovine $1 \%$.

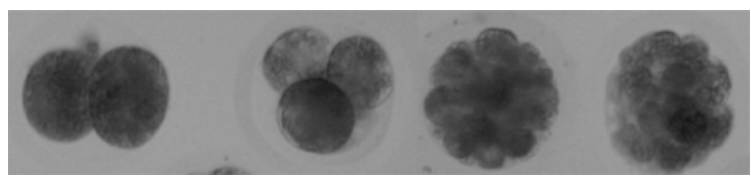

Figure 2. Development of intergeneric cloned embryo using bovine oocyte recipient

\section{Discussion}

In this study wanted to learn about intergeneric cloned dog using bovine and porcine oocyte as cytoplasm donor. We used both kind of oocyte because limitation of oocytes from canine species and ones of the reason we used interspecies nuclear transfer was limitation of oocyte source and several studies using cytoplasm. This reason also supported by delivery of mouflon ( Loi et al., 2001) and gaur (Lanza et al., 2000) which using interspecies too and also successful of bovine oocyte to support development of embryos from another species (Dominko et al., 1999; Arat et al., 2001; Hwang et al., 2001; Bui et al., 2002).

In this present study we found that canine intergeneric nuclear transfer using pigs and cows oocytes as recipient oocytes have no different result in fusion condition and this result almost same with result used in porcine cloning around $68-75 \%$ (Hao et al., 2003; Hyun et al., 2003). A majority of the fused embryos in this study initiated cleavage and developed to the 16 cell stage of development. However, development rate after 16-cell is very low and no blastocyst stage achievement in this experiment. It would be expected that intra- or inter-generic reconstituted embryos would undergo cleavage because maternally inherited gene products that are stored in the oocyte regulate the earliest stages of embryogenesis (Memili and First, 2000). The earliest stages of embryogenesis in normal embryos are regulated by maternally inherited gene products stored within the oocyte cytoplasm. Progression of development becomes dependent on embryonic gene activation at a species-specific developmental stage (Telford et al., 1990). This occurs at the 2- to 
4-cell stage in rats (Ansai et al., 1994), late 4cell stage in cattle (Jones et al., 2001) and pig (Prather, 1993), and 8-cell stage in sheep (Crosby et al., 1988) and at 4- to 8-cell stage in human embryos (Braude et al., 1988).

In this study we get development block after 16 sel stage with show the lower development to the morula and no blastocyst stages. There are many factors that can interfere in embryo development causing embryo cleavage to cease, and two main mechanisms are believed to cause the embryo developmental block are inability to overcome the chromatin repression and (i) active transcription of important developmental genes and/or (ii) to react to injuries caused by environment. Most of the embryo block occurs during the fourth or between the fourth and fifth cell cycle transition (Memili and First, 2000). This developmental block is observed in many species, with the peculiarity that it shows up at different stages in different species. This species-specific block moment is concurrent with maternal-embryo transition, the development stage when embryos conclude the mayor genome activation and must rely on the mRNAs transcribed from its own genome to continue development (Meirelles et al., 2004).

Table 4. Effect of bovine and porcine oocyte as cytoplasm donor in canine intergeneric nuclear transfer

\begin{tabular}{cccccccc}
\hline $\begin{array}{c}\text { Oocyte } \\
\text { recipi- } \\
\text { ent }\end{array}$ & $\begin{array}{c}\text { No. of } \\
\text { oocy- }\end{array}$ & $\begin{array}{c}\text { Fusion } \\
\text { tes }\end{array}$ & & $\begin{array}{c}\text { Cleav- } \\
\text { age (\%) }\end{array}$ & \multicolumn{3}{c}{$\begin{array}{c}\text { No. (\%) of intergeneric } \\
\text { embryo }\end{array}$} \\
\cline { 5 - 8 } & & & & & $\begin{array}{r}2 / 4 \\
\text { cell }\end{array}$ & $\begin{array}{r}8 / 16 \\
\text { cell }\end{array}$ & ula \\
\hline \multirow{2}{*}{ Bovine } & 274 & 181 & 106 & 49 & 55 & 2 \\
& & $(66)$ & $(58)$ & $(45)$ & $(51)$ & $(1)$ \\
\hline Porcine & \multirow{2}{*}{303} & 209 & 152 & 66 & 83 & 3 \\
& & $(68)$ & $(72)$ & $(43)$ & $(54)$ & $(1)$ \\
\hline
\end{tabular}

In vitro developmental block has been observed using interspecies methods. It has been suggested that mitochondrial mismatch between donor cell and recipient oocyte could be a cause for the embryonic developmental arrest. Continuation of development could be a consequence of efficient reprogramming of the donor nucleus, regardless of the species, followed by now embryonic gene expression. Alternatively, it could indicate incompatibilities between the new components synthesized by the donor nucleus and the components left over from the recipient cytoplasm. In this case, the introduced fibroblast nucleus would be directing cell proliferation, and the resulting multicellular structure would have few or no embryonic characteristics. Observations of embryo-like structures containing a high number of cells that would not undergo compaction support the latter scenario (Lee et al., 2003). Expression of specific genes has been shown to be required for compaction and cavitation in developing embryos. Absence of compaction in some embryos in this study would suggest lack of or impairment in transcription of genes required for these differentiation events to occur (De sousa et al., 1999; Watson et al., 2000).

Several studies have reported inheritance of mitochondrial and mitochondrial DNA (mtDNA) after nuclear transfer procedure. Sheep (Evans et al., 1999) and calves (Takeda et al., 1999) produce by somatic nuclear transfer have been reported to inherit their mitochondria entirely from the oocyte and not from the donor cell. However, indication of the presence of heteroplasmy after NT and the potential for mitochondrial mismatch could possibly impair embryo development (Nagao et al., 1998). Steinborn et al. (2000) reported that mtDNA heteroplasmy in cloned cattle generated from fetal and adult donor cell. 
mtDNA also reported to be present in somatic cell NT-derived embryos by allelespecific PCR, direct squencing and DNA chromatography of the D-loop region (Do et al., 2002). Interestingly, Nagao et al. (1998) reported, decreasing physical performance in congenic mice with mismatch between the nuclear and the mitochondrial genome. When foreign mitochondrial are introduced in conducting interspecies NT procedures, it is possible that mitochondrial heteroplasmy, as well as chromosome number, may be key factors that affect embryonic development and in utero survivability of interspecies NT embryos (Sansinena et al., 2005).

\section{Conclusion}

For intergeneric nuclear transfer, oocytes from bovine and porcine can dedifferentiated canine nucleus and no different between bovine and porcine oocyte in fusion or embryo development in vitro. Canine intergeneric cloned embryos developed to morula stages in vitro.

\section{Acknowledgments}

This study was done in Laboratory of Theriogenology and Biotechnology, College of Veterinary Medicine Seoul National University. The author acknowledge to my professor, Hwang Woo-Suk, Ph.D., Lee Byeong-Chun, Ph.D. and Kang Song-Keun, Ph.D for their support to my study in this laboratory.

\section{References}

Ansai, T., Ikeda, A., Toyoda, Y. and Takahashi, M., 1994. The chronologically defined developmental process of rat preimplantation embryos. J. Reprod. Dev. 40, 33-38.

Arat, S., Rzucidlo S.J., Gibbons, J., Miyoshi, K. and Stice, S.L., 2001. Production of transgenic bovine embryos by transfer of transfected granulosa cells into enucleated oocytes. Mol. Reprod. Dev. 60, 20-26.

Braude, P., Bolton, V. and Moore, S., 1988. Human gene expression first occurs between the four- and eight-cell stages of preimplantation development. Nature. 332, 459-461.

Bui, L., Vignon, X. and Campion, E., 2002. Use of interspecies nuclear transfer to study the early embryonic development and buclear activities of the endangered species Pseudoryx nghetinhensis (Saola). Theriogenology, 57, 427

Chen, D.Y., Wen, D.C., Zhang, Y.P., Sun, Q.Y., Han, Z.M., Liu, Z.H., Shi, P., Li, J.S., Ziangyu, J.G., Lian, L., Kou, Z.H., Wu, Y.Q., Chen, Y.C., Wang, P.Y. and Zhang, H.M., 2002. Interspecies implantation and mitochondria fate of panda-rabbit cloned embryos. Biol. Reprod., 67, 637-642.

Choi, Y.H., Lee, B.C., Lim, J.M., Kang, S.K. and Hwang, W.S., 2002. Optimization of culture medium for cloned bovine embryos and its influence on pregnancy and delivery outcome. Theriogenology, 58, 1187-1197.

Cibelli, J.B., Stice, S.L., Golueke, P.J., Kane, J.J., Jerry, J., Blackwell, C., Ponce de Leon, A. and Robl, J.M., 1998. Cloned transgene calves produced from nonquiescent fetal fibroblasts. Science, 280, 1256-1258.

Cohen, J., 1997. Can cloning help save endangered species?. Science, 276, 13291330.

Crosby, I.M., Gandolfi, F. and Moor, R.M., 1988. Control of protein synthesis during early cleavage of sheep embryos. J. Reprod. Fertil., 82, 769-775

Damiani, P., Wirtu, G., Miller, F., Cole, A., Pope, C. and Godge, R.A., 2003. Development of giant eland (Taurotragus oryx) and bovine (Bos Taurus) oocytes. Theriogenology, 59, 390 (abstract). 
De Sousa, P.A., Winger, Q., Hill, J.R., Jones, K., Watson, A.J. and Westhusin, M.E., 1999. Reprogramming of fibroblast nuclei after transfer into bovine oocytes. Cloning, 1, 63-69

Do, J.T., Lee, B.Y., Kim, S.B., Ryoo, Z.Y. and Lee, H.T., 2002. Fate of donor mitochondrial DNA in cloned bovine embryos produced by microinjection of cumulus cells. Biol. Reprod., 67, 555-560

Dominko, T., Mitalipova, M. and Haley, B., 1999. Bovine oocyte cytoplasm supports development of embryos produces by nuclear transfer of somatic cell nuclei from various mammalian species. Biol. Reprod., 60, 1496-1502.

Evan, M.J, Gurer, C., Loike, J.D., Wilmut, I., Schnieke, A.E. and Schon, E.A., 1999. Mitochondrial DNA genotypes in nuclear transfer-derived cloned sheep. Nat. Genet., 23, 90-93

Hao, Y., Lai, L., Lim, G.S., Bonk, A. and Prather, R.S., 2003. Apoptosis and in vitro development of preimplantation porcine embryo in vitro or by nuclear transfer. Biol. Reprod., 69 (2), 501-507

Hwang, W., Kim, K., Kim, G., Jin, Y., Kim, Y., Chung, H., Yoon, F., Han, C., Eo, Y. and Lee, B., 2001. Interspecies somatic cell nuclear transfer for the production of endangered Korean tiger (Panthera tigris altaica). Theriogenology, 55, 271.

Hyun, S.H., Lee, G.S., Kim, D.Y., Kim, H.S., Lee, S.H., Kim, S., Lee, E.S., Lim, J.M., Kang, S.K., Lee, B.C. and Hwang, W.S., 2003. Effect of maturation media and oocytes derived from sows or gilts on the development of cloned pig embryos. Theriogenology, 59, 1641-1649.

Jones, K.L., Hill, J., Shin, T.Y., Lui, L. and Westhusin, M., 2001 DNA Hypomethylation of karyoplasts for bovine nuclear transplantation. Mol. Reprod. Dev. 60, 208-213.

Jumnian, S., Kanok, P., Mayurachat, J. and Yindee, K., 2002. Xenonuclear
Transplantation of buffalo (Bubalus bubalis) fetal and adult somatic cell nuclei into bovine (Bos indicus) oocyte cytoplasm and their subsequent development. Theriogenology, 57, 18291837.

Lanza, R.P., Cibelli, J.B. and West, M.D., 1999. Human therapeutic cloning. Nat. Med., 5, 975-977.

Lanza, R.P., Civelli, J.B. and Diaz, F., 2000. Cloning of endangered species (Bos gaurus) using interspecies nuclear transfer. Cloning, 2, 79-90.

Lee, B.C., Wirtu, G.G., Damiani, P., Pope, E., Dresser, B.L., Hwang, W.S. and Bawister, B.D., 2003. Blastocyst development after intergeneric nuclear transfer of Mountain Bongo antelope somatic cells into bovine oocytes. Cloning and Stem Cells, 5 (1), 25.

Loi, P., Ptak, G., Barbony, B., Fulka, J.Jr., Cappai, P. and Clinton, M., 2001. Genetic rescue of endangered mammals by cross-species nuclear transfer using post mortem somatic cells. Nature Biotech., 19, 962-964.

Lu, F., Shi, D., Wei, J. and Wei, Y., 2005. Developmetnt of embryos reconstructed by interspecies nuclear transfer of adult fibroblast between buffalo (Bubalus bubalis) and cattle (Bos indicus). Theriogenology, 64 (6), 1309 1319.

Meirelles, F.V., Caetano, A.R., Watanabe, Y.F., Ripamonte, P., Carambulla, S.F., Merighe, G.K. and Garcia, S.M., 2004. Genome activation and developmental block in bovine embryos. Animal Reprod. Sci., 82 (83), 13-20.

Memili, E. and First, N.L., 2000. Zygotic and embryonic gene expression in cow: a review of timing and mechanism of early gene expression as compared with other species. Zygote, 8, 87-96.

Nagao, T.D., Totsuka, Y., Atomi, Y., Kaneda, H., Lindahl, K.F., Imai, H., 1998. 
Decreased physical performance of congenic mice with mismatch between the nuclear and the mitochondrial genome. Genet. Genet. Syst., 73, 21-27.

Prather, R.S., 1993. Nuclear control of early embryonic development in domestic pig. J. Reprod. Fertil. Suppl., 48, 17-29.

Sansinena, M.J., Hylan, D., Hebert. K., Denniston, R.S. and Godke, R.A., 2005. Banteng (Bos javanicus) embryos and pregnancies produced by interspecies nuclear transfer. Theriogenology, 63, 1881-1091.

Steinborn, R., Schinogl, P., Zakhartchenko, V., Achmann, R., Schernthaner, W. and Stojkovic, M., 2000. Mitochondrial DNA heteroplasmy in cloned cattle produced by fetal and adult cell cloning. Nat. Genet., 25, 255-257.

Takeda, K., Takahasih, S., Onishi, A., Goto, Y., Miyazawa, A. and Imai, H., 1999. Dominant distribution of mitochondrial DNA from recipient oocytes in bovine embryos and offspring after nuclear transfer. J. Reprod. Fertile, 116, 253-259.

Telford, N.A., Watson, A.J. and Schultz, G.A., 1990. Transition from the maternal to embryonic control in early mammalian development: a comparison of several species. Mol. Reprod. Dev., 26, 90-100.

Vogel, G., 2001. Endangered species. cloned gaur: a short-lived success. Science, 291, 409.

Watson, A.J, De Sousa, P., Caveney, A., Barcroft, L.C., Natale, D., Urquhart, J.,
Westhusin, M.E., 2000. Impact of bovine oocyte maturation media on oocyte transcript levels, blastocyst development, cell number, and apoptosis. Biol. Reprod., 62, 355-364.

Wen, D.C., Yang, C.X., Cheng, Y., Li, J.S., Liu, Z.H., Sun, Q.Y., Zhang, J.X., Lei, L., Wu, Y.Q., Kou, Z.H. and Chen, D.Y., 2003. Comparison of developmental capacity for intra and inter-species cloned cat (Felis catus) embryo. Mol. Reprod. Dev., 66, 34-45.

Wen, D.C., Bi, C.M., Xu, Y., Yang, C.X., Zhu, Z.Y., Sun, Q.Y. and Chen, D.Y., 2005. Hybrid embryos produced by transferring panda or cat somatic nuclei into rabbit MII oocytes can developmental to blastocyst in vitro. J. Exp. Zoo., 303A, 689-697.

White, K.L., Bunch, T.D., Mitalipov, S., Reed, W.A., 1999. Establishment of pregnancy after the transfer of nuclear transfer embryo produced from the fusion or argali (Ovis ammon) nuclei into domestic sheep (Ovis aries) enucleated oocyte. Cloning, 1, 47-54.

Wilmut, I., Schnieke, A.E., McWhir, J., Kind, A.J. and Campbell, K.H.S., 1997. Viable offspring derived from fetal and adult mammalian cells. Nature, 385, 810-813.

Woods, G.L., White, K.L., Vanderwall, D.K., Li, G.P., Aston, K.I., Bunch, T.D., Meerdo, L.N. and Pate, B., 2003. A mule cloned from fetal cells by nuclear transfer. Science, 301, 1063. 